\title{
Social Mobility of Immigrants in Canada *
}

\author{
ANTHONY H, RICHMOND
}

The object of this paper is to examine some of the operational problems that arose in studying the social mobility of post-war immigrants in Canada and to present the findings of a survey concerning the pattern and degree of mobility exhibited by the immigrants. The research was part of an extensive survey of the economic and social absorption of post-war immigrants carried out in association with the Dominion Bureau of Statistics and the Research Division of the Canadian Department of Citizenship and Immigration. ${ }^{1}$

The sample was based upon a monthly labour force survey carried out by the Dominion Bureau of Statistics. The latter is a I per cent sample of the total Canadian population, but the immigrant households studied were drawn from a sub-sample of $x$ in 6 households in the general sample, giving a sampling ratio of $\mathrm{I}$ in 600 . The initial sample consisted of 692 heads of households or economically independent persons, including 86 women, who were post-war immigrants. Information was collected by means of a questionnaire completed by the immigrants themselves and mailed to the Research Division in Ottawa in February 196r. A response rate of 69 per cent was obtained, after the enumerators who had originally distributed the questionnaire had called a second time upon those who had not responded within one month. This gave a total of 478 completed questionnaires for the national sample. ${ }^{2}$ Information about non-respondents provided by the Dominion Bureau of Statistics showed that the sample of respondents was fully representative with regard to age, sex and occupation. There was, however, a slight underrepresentation of single people and of immigrants from Mediterranean countries.

Various measures were designed to assess the changes which have taken place between the socio-economic position of the immigrants in their former countries and that which had been achieved in Canada. An objective measure of standard of living was devised based upon the difference between the number of household amenities possessed in the former country and the number possessed in Canada. ${ }^{3}$ On this basis it was found that 9 per cent of the immigrants had the

* Revised version of a paper presented at a meeting of the Scottish Branch of the British Sociological Association, held in Edinburgh, 4th May 1963.

I The study was initiated when the author was appointed Canada Council and Koerner Visiting Fellow and Lecturer at the University of British Columbia, 1960-6r. I am indebted to the Milbank Memorial Fund of New York and to the Government of Canada for grants towards research expenses. I should like to express my thanks to the Director and staff of the Research Division, Department of Citizenship and Immigration, Ottawa, for their practical assistance at every stage of the research.

${ }^{2}$ Information was also obtained from a special sample of immigrants in Vancouver for comparison with the national sample, but the results are not discussed in this paper.

${ }^{3}$ Amenities included central heating; exclusive use of hot and cold running water, inside toilet and bath or shower; refrigerator; washing machine; vacuum cleaner; telephone; television and automobile. 
same or fewer amenities as in the former country; 63 per cent had up to six more amenities and 27 per cent had between seven and ten more amenities. A subjective measure of the change in the immigrants' standard of living was used in which 36 per cent of the respondents said that they were very much better off in Canada; 40 per cent that they were a little better off; 17 per cent that they were the same; 4 per cent that they were a little worse off and 3 per cent that they were very much worse off. A subjective measure of social status mobility was also used in which the respondent was asked to indicate whether he thought his position in the community had risen, remained the same or fallen, compared with his former country. Thirty-three per cent of the respondents thought their position had risen; 53 per cent that it was the same and 14 per cent that it had fallen.

However, the main source of information used in the study of social mobility was the information provided by the informants concerning their own and their fathers' occupations. The immigrants were asked to indicate the father's occupation when he was the same age as the informant; their own occupation in their former country; their first occupation in Canada and the occupation at the time of the survey. This enabled an assessment to be made of intergenerational mobility before migration, and intergenerational mobility achieved since migration, together with the pattern of intragenerational mobility consequent upon the migration itself.

The question immediately arose as to how the occupations were to be classified. The immigrants came from a large number of different countries whose economic structure differed. While the majority of immigrants came from urban backgrounds about 17 per cent had been in agriculture or other primary industries in their former country. It was necessary to adopt a single classification of occupations that could be used for all countries and for all stages in the intergenerational and intragenerational comparisons. This procedure overcame some of the difficulties which have been faced by sociologists attempting international comparisons of rates of social mobility where different occupational scales have been adopted in the various countries. ${ }^{4}$ At the same time it did not remove the objection that the occupational structure varied from country to country and that the criteria for evaluating social status were probably also different. However, the comparative studies by Inkeles suggested that the difference in occupational prestige between urban industrial societies is not substantial and that some consensus probably exists between them. ${ }^{5}$

The four occupations reported by the respondent, that of his father, his own occupation in his former country, his first job in Canada and his job at the time of the survey were, first of all, coded on the classification used by the Dominion Bureau of Statistics in the I96I census of Canada. ${ }^{6}$ This classification was a modified version of the International Standard Classification of Occupations recommended by the I.L.O. but it had certain basic disadvantages as a means of measuring occupational status mobility. Its main categories were descriptive of the type of employment but

\footnotetext{
${ }^{4}$ For a discussion of the problems involved in making international comparisons of social mobility see S. M. Lipset and Reinhard Bendix, Social Mobility in Industrial Society, Berkeley, 1959, and S. M. Miller, 'Comparative social mobility', Current Sociology, 9, I, 1960.

'A. Inkeles and P. Rossi, 'National comparisons of occupational prestige', American fournal of Sociology, 5x, 4, 1956 pp. 329-339

- Occupational Classification Manual, Census of Canada, 196I, Dominion Bureau of Statistics, Ottawa April r96r.
} 
grouped together people of very different levels of education and income. Thus, for example:

Division I: Managerial occupations on the Dominion Bureau of Statistics classification include owners of one-man businesses and persons in lower levels of administration.

Division 2: Professional and technical occupations include laboratory technicians as well as the higher professional occupations.

Division 7: Consists of farm owners and farm workers.

In other divisions manual occupations are grouped according to the kind of work without regard to the level of skill required.

In order to overcome this difficulty use was made of the scale of occupational status devised by Professor Bernard Blishen of the University of British Columbia. ${ }^{7}$ The Blishen occupational class scale was based upon the I95I census of Canada. The 343 main occupational groupings in the census classification of occupations were first ranked according to the mean income and mean years of schooling. From these data standard scores were computed for education and income, and each occupation rated according to this combined score. ${ }^{8}$ The scores ranged from $32^{\circ} \circ$ for hunters and trappers at one end of the scale, to $90^{\circ} \circ$ for judges at the other end. Bus drivers scored $47^{\circ} 6$; compositors 50.4 and university professors $72 \cdot 0$. Blishen assumed that the combination of income and education as criteria would reflect the prestige ranking of occupations in Canada and in other countries. The only other Canadian study with which he was able to make comparisons was that of Tuckman. ${ }^{9}$ The latter included only 18 occupations in its list which were ranked by informants in order of prestige. Blishen showed that the rank correlation between his classification and Tuckman's was 0.9r. He found, also, that his scale correlated closely with the one devised by the National Opinion Research Centre in the United States (with a correlation of 0.94) and with prestige scales used in Germany, Great Britain, New Zealand and Japan.

In addition to scoring occupations on the basis of average income and education at the time of the I95I census Blishen divided his occupations into seven classes, though the boundaries between classes were somewhat arbitrary. They were based upon his own awareness of the relative prestige ranking of occupations. In view of the close correlation of Blishen scores and other classifications of occupational status used in studies of social mobility in various countries, it was felt that Blishen scores would be a useful means of measuring the occupational status mobility of immigrants in Canada. However, the Blishen scale of classes had the disadvantage of cutting across the broad occupational distinctions between professional, managerial, clerical, skilled, semi- and unskilled workers that are a familiar feature of such scales as those by the Registrar General in Britain or the

'Bernard R. Blishen, 'The construction and use of an occupational class scale' Canadian fournal of Economics and Political Science, 24, 4, 1958, pp. 519-531.

${ }^{8}$ In so far as these scores reflected average education and income in each occupational category, they did not take into account the considerable range of income often exhibited within the category. This presented difficulties when Blishen scores were used to compute the social mobility of immigrants. For example, if an immigrant's first job in Canada was reported as 'Civil Engineer' his score would be $75^{\circ}$. If he subsequently became manager of a firm, his Blishen score, strictly speaking, fell to $63 \cdot 8$. However, when the internal evidence from the questionnaire showed that the change of occupation had resulted in an increase or no loss of income his original Blishen score was retained.

'Jacob Tuckman, 'The social status of occupations in Canada', Canadian fournal of Psychology 1, 1947, pp. 71-94. 
Hall-Jones classification of occupational prestige. ${ }^{10}$ In the Blishen classes there is no clear-cut distinction between manual and non-manual workers which has been shown to be an important boundary in the study of social mobility.

Therefore, a third occupational classification was devised for analysing the data on the social mobility of immigrants in Canada ${ }^{11}$. This was a combination of the Dominion Bureau of Statistics census classification and the Blishen score, or the known years of education. The occupations of immigrants were coded on the Dominion Bureau of Statistics scale and the Blishen score. When the information was punched on to cards a further sort was undertaken which eliminated from the Dominion Bureau of Statistics category of professionals all those with less than 13 years of education. These were grouped into a special intermediate category of lower professional, other managerial and technical workers. Manual occupations were divided into two according to Blishen score, providing a group of highly skilled manual workers with scores above 44.4 points and a further group of other skilled, semi-skilled and unskilled workers. The new scale of socio-economic status consisted, finally, of six classes and residual groups of persons not in the labour force or about whom sufficient information was not available. The classes were as follows:

I. Managers, executives and senior civil servants: consisting of D.B.S. Division I (excluding small owners and junior managers) together with such occupations as real estate agents and stockbrokers from Division 4 .

2. Higher Professional: consisting of D.B.S. Division 2 (excluding the lower professional and technical occupations) together with commissioned officers from Division 5.

3. Intermediate:

consisting of lower professional, junior managerial and technical occupations.

4. Clerical and Sales:

consisting of the whole of D.B.S. Division 3 together with the remainder of Division 4 .

5. Highly skilled:

consisting of all manual workers with Blishen scores above $44 \cdot 4$, ranging from locomotive engineers to construction machine operators.

6. Other skilled, semi-skilled and unskilled:

consisting of manual workers with Blishen scores of 44.4 and below, ranging from blacksmiths, carpenters and cooks to general labourers.

An attempt was made to validate the new scale by calculating the mean incomes and average years of education of immigrants in each class as reported in the survey. The results showed that the managers in Class I had the highest incomes, but the professionals in Class 2 the longest period of education. Managers in Class I had more education than the immigrants in the intermediate Class 3. The latter had more education and higher incomes than the clerical workers in Class 4,

\footnotetext{
${ }^{10}$ John Hall and D. Caradog Jones, 'The social grading of occupations', British fournal of Sociology r, I March 1950.

${ }^{11}$ I am indebted to Dr. R. Sylt of the Research Division, Department of Citizenship and Immigration, Ottawa, who undertook the technical preparation of this scale.
} 
among whom there was a high proportion of women. Skilled workers had less education but earned more than clerical workers, and the immigrants in Class 6 had the lowest levels of education and income. The scale, therefore, appears to be consistent with expected distributions of income and education and to be a valid measure of socio-economic status.

TABLE I. Socio-economic status of immigrants and their fathers

UNITED KINGDOM

\begin{tabular}{|c|c|c|c|c|c|c|c|c|}
\hline \multirow[b]{2}{*}{ Code:* } & \multicolumn{2}{|c|}{ Father's occupation } & \multicolumn{2}{|c|}{ Former occupation } & \multicolumn{2}{|c|}{ First job in Canada } & \multicolumn{2}{|c|}{ Job: February I96I } \\
\hline & No. & Per cent & No. & Per cent & No. & er cent & No. & er cent \\
\hline I & $I I$ & $8 \cdot 9$ & Io & $8 \cdot 1$ & 7 & $5 \cdot 7$ & I5 & $I 2 \cdot I$ \\
\hline 2 & I4 & $11 \cdot 3$ & 7 & 5.7 & 6 & $4 \cdot 8$ & 7 & $5 \cdot 7$ \\
\hline 3 & 5 & $4 \cdot 0$ & I8 & 14.5 & I6 & I2.9 & 19 & $15 \cdot 3$ \\
\hline 4 & 14 & II $\cdot 3$ & 26 & $2 I \cdot 0$ & 24 & $19 \cdot 4$ & $2 I$ & 16.9 \\
\hline 5 & $5 I$ & $4 I \cdot I$ & 37 & $29 \cdot 8$ & 32 & $25 \cdot 8$ & 33 & $26 \cdot 6$ \\
\hline 6 & 13 & 10.5 & 15 & I2.I & $3 I$ & $25 \cdot 0$ & 18 & $14: 5$ \\
\hline 7 & I & $0 . \overline{8}$ & 8 & $6 \cdot 5$ & 4 & $3 \cdot 2$ & II & $8 \cdot 9$ \\
\hline- & I5 & $12 \cdot 1$ & 3 & $2 \cdot 4$ & 4 & $3 \cdot 2$ & - & - \\
\hline Total & 124 & 100 & 124 & 100 & I24 & 100 & 124 & 100 \\
\hline
\end{tabular}

NON-UNITED KINGDOM

\begin{tabular}{|c|c|c|c|c|c|c|c|c|}
\hline I & 29 & $8 \cdot 2$ & I0 & $2 \cdot 8$ & 5 & $\mathrm{I} \cdot 4$ & II & $3 \cdot I$ \\
\hline 2 & 28 & $7 \cdot 9$ & 21 & $5 \cdot 9$ & 14 & $4^{\circ}$ & 19 & $5 \cdot 4$ \\
\hline 3 & I5 & $4 \cdot 2$ & 16 & 4.5 & 6 & I.7 & 12 & $3 \cdot 4$ \\
\hline 4 & 20 & $5 \cdot 6$ & 37 & 10.5 & IO & 2.8 & 30 & 8.5 \\
\hline 5 & 105 & $29 \cdot 7$ & 94 & $26 \cdot 6$ & 70 & $19 \cdot 8$ & I 16 & $32 \cdot 8$ \\
\hline 6 & IIO & $3 I \cdot I$ & 119 & $33 \cdot 6$ & 218 & $6 I \cdot 6$ & I5I & $42 \cdot 7$ \\
\hline 7 & 2 & 0.6 & 33 & $9 \cdot 3$ & IO & $2 \cdot 8$ & IS & $4 \cdot 2$ \\
\hline- & 45 & I2.7 & 24 & 6.8 & $2 I$ & $5 \cdot 9$ & - & - \\
\hline Total & 354 & 100 & 354 & 100 & 354 & 100 & 354 & 100 \\
\hline
\end{tabular}

* Code: I-Higher managerial. 5 - Highly skilled.

2-Higher professional. $\quad 6$-Other skilled, semi-skilled and unskilled.

3 - Intermediate.

4 - Clerical and sales. $\quad--$ No reply.

Table I shows the distribution of occupations on this scale, comparing immigrants from the United Kingdom with those from other countries in terms of father's occupation, own occupation in former country, first job in Canada (held for two months or more), ${ }^{12}$ and occupation at the time of the survey. Immigrants from the U.K. constituted about a quarter of the total immigrant population in 196I. Those from other countries consisted of 3 per cent from other English-speaking countries, 2 per cent from Asian countries and the remainder, constituting 70 per cent of the total, from various countries of Europe. When U.K. immigrants are compared with the others at the time

12 Immigrants are encouraged to take any job they can get as a temporary measure on first arriving in Canada. By asking for 'first job held for two months or more' purely stop-gap employment of this kind was excluded from consideration. 
of the survey it is found that 43 per cent of the latter fell into the bottom social class compared with only 14.5 per cent of the immigrants from the U.K. At the other end of the scale approximately I 8 per cent of the U.K. immigrants were in the top two social classes compared with only 8.5 per cent of the others. In this respect the post-war immigrant population reinforced the status differences which were already evident in the Canadian population between those of British descent and those who were of some other ethnic origin. Blishen showed that, at the time of the r95I census, Canadians of British descent were underrepresented in the lowest social classes and overrepresented in the top class compared with French-Canadians and those of other ethnic origins. ${ }^{13}$

\section{INTERGENERATIONAL MOBILITY}

It is evident, therefore, that in studying the social status and social mobility of post-war immigrants in Canada it is essential to distinguish between the experience of the U.K. immigrants and those from other countries. We may begin by examining the pattern of intergenerational mobility. When the occupations of fathers are considered there are no significant ${ }^{14}$ differences between U.K. immigrants and others in the proportion having fathers in Classes $I, 2$ and 3. However, the U.K. immigrants have a higher proportion of fathers in Classes 4 and 5 consisting of routine clerical workers and skilled manual workers. They have a significantly lower proportion in the category of other unskilled and semi-skilled workers. It is possible to compare the father's occupation with that of the migrant in his former country and that pursued by the migrant at the time of the survey. Table 2 shows that among the U.K. immigrants whose fathers were non-manual workers, 66 per cent were in non-manual employment in the former country and 77 per cent in non-manual employment in Canada. This contrasts with the experience of immigrants from other countries. In their case, of those with fathers in non-manual occupations 51 per cent were themselves in non-manual employment in their former country and only 40 per cent in Canada. In other words, the process of emigration had enabled the children of white-collar workers in the U.K. to retain or improve their position, whereas those from other countries fell in status. Clearly, this process was related to the question of language and of professional qualifications, both of which presented greater obstacles to the immigrant from Europe than from the U.K. In the case of highly skilled workers there was almost exactly the same proportion of those from the U.K. and those from other countries who had the same status as their fathers in their former country. Furthermore, in the case of both U.K. immigrants and the others, the same proportion of those whose fathers were in highly skilled occupations achieved this status in Canada. However, of those who moved out of highly skilled occupations the majority of the U.K. immigrants moved up into white-collar employment, whereas the majority of other immigrants moved down into semi-skilled or unskilled types of employment. Only a very small proportion of the immigrants from the U.K. had fathers in semiskilled or unskilled employment and of these only I5 per cent in the former country and $3 \mathrm{I}$ per

${ }^{13}$ Loc. cit., p. 524.

14 In this paper no differences are described as 'significant' that could occur more than once in 40 times in a random sample of the same size. When allowance is made for 'clustering' and other effects this is equivalent to $P<0.05$. See Appendix for results of tests of significance. 
TABLE 2. Intergenerational mobility of post-war immigrants in Canada. (Outflow analysis) NON-UNITED KINGDOM ORIGIN

MigRants' OCCUPATIONS

\begin{tabular}{|c|c|c|c|c|c|c|c|c|c|c|}
\hline \multirow{3}{*}{$\begin{array}{l}\text { Father's } \\
\text { occupation }\end{array}$} & \multicolumn{2}{|c|}{$x-4$} & \multicolumn{2}{|c|}{5} & \multicolumn{2}{|c|}{6} & \multicolumn{2}{|c|}{7} & \multicolumn{2}{|c|}{ Total } \\
\hline & Former & $\begin{array}{l}\text { Can. } \\
\text { I96I }\end{array}$ & Former & $\begin{array}{l}\text { Can. } \\
\text { I96I }\end{array}$ & Former & $\begin{array}{l}\text { Can. } \\
\text { Ig6I }\end{array}$ & Former & $\begin{array}{l}\text { Can. } \\
\text { I96I }\end{array}$ & & \\
\hline & $\begin{array}{l}\text { Per } \\
\text { cent }\end{array}$ & $\begin{array}{l}\text { Per } \\
\text { cent }\end{array}$ & $\begin{array}{l}\text { Per } \\
\text { cent }\end{array}$ & $\begin{array}{l}\text { Per } \\
\text { cent }\end{array}$ & $\begin{array}{l}\text { Per } \\
\text { cent }\end{array}$ & $\begin{array}{l}\text { Per } \\
\text { cent }\end{array}$ & $\begin{array}{l}\text { Per } \\
\text { cent }\end{array}$ & $\begin{array}{l}\text { Per } \\
\text { cent }\end{array}$ & $\begin{array}{l}\text { Per } \\
\text { cent }\end{array}$ & No. \\
\hline$I-4$ & $5 I$ & 40 & 25 & 30 & IO & 28 & 14 & $\mathbf{I}$ & 100 & 92 \\
\hline 5 & 18 & 14 & 35 & 43 & $3 I$ & 33 & I5 & IO & 100 & 105 \\
\hline 6 & 7 & 12 & 23 & 21 & 58 & 66 & 12 & $\mathbf{I}$ & 100 & IIO \\
\hline 7 & $2 I$ & 15 & 19 & 43 & 28 & 36 & 32 & 6 & 100 & 47 \\
\hline
\end{tabular}

UNITED KINGDOM ORIGIN

Migrants' Occupations

\begin{tabular}{l|rr|rr|rr|rr|rr}
\hline$x-4$ & 66 & 77 & 16 & 7 & 9 & 9 & 9 & 7 & 100 & 44 \\
5 & 37 & 37 & 37 & 43 & 16 & 14 & 10 & 6 & 100 & 51 \\
6 & 31 & 31 & 54 & 38 & 15 & 31 & - & - & 100 & 13 \\
7 & 56 & 31 & 25 & 19 & 6 & 19 & 13 & 31 & 100 & 16 \\
\hline
\end{tabular}

* Code: I-4 Non-manual.

5 Highly skilled.

6 Other skilled, semi-skilled and unskilled.

7 Not in labour force and not known: includes students and other non-employed together with those about whom information was not available.

cent in Canada remained in this status. In contrast, immigrants from other countries had the highest proportion with fathers in the lowest category and 58 per cent were in this group in the former country compared with 66 per cent in Canada.

It is evident, therefore, that the intergenerational mobility of U.K. immigrants compared with the others is of a rather different character. Whether one considers the occupations of the immigrants in their former country or those of their fathers it appears that the emigration from Britain is, principally, of people with middle-class or upper working-class backgrounds. Only I2 per cent of the British immigrants, compared with one-third of those from other countries, were from semi-skilled or unskilled occupations. In the case of the I5 U.K. immigrants in the sample who were in semi-skilled or unskilled employment in their former country, $\mathrm{I} 2$ had fathers who were in higher status occupations. This suggests that British people with lower working-class backgrounds do not 
often emigrate to Canada. In contrast, the movement of European immigrants is much more proletarian. There are a number of reasons for this difference. In the first instance, it is well known that unskilled manual workers in Britain appear to have a strong attachment to the locality of their birth and upbringing and are often reluctant to move, even to another part of Britain, let alone to emigrate. ${ }^{15}$ If they are tempted to do so, they might be more attracted by the prospects in Australia as an almost free passage is provided. Furthermore, Canadian Government immigration officers in Britain would probably discourage a prospective emigrant who had no special skills to offer. In contrast, Canadian immigration policy in Europe has tended to encourage the migration of unskilled workers. In the period immediately after the Second World War there was a demand for farm labour, and the movement from refugee camps in Europe tended to be of people with relatively low educational levels. Subsequently, the Canadian Government adopted stricter occupational requirements for its open-placement immigrants, but unskilled workers with low. educational attainment continued to enter Canada sponsored by their close relatives. Under the Canadian Immigration Act and Regulations certain Canadian residents could sponsor a first-degree relative so long as they guaranteed that the new immigrant would not become a public charge. Over a period of years this movement of sponsored relatives tended to snowball and was particularly marked from Italy. The Canadian Government attempted, in 1959, to impose an occupational skill requirement upon sponsored immigrants but was prevented from so doing by political pressures.

Before leaving the question of intergenerational mobility, it is interesting to compare the experience of post-war immigrants from Britain to Canada with that of the population studied by Professor D. V. Glass and his associates. ${ }^{16}$ Obviously the small size of the migrant sample makes it necessary to be very cautious in interpreting the evidence. Furthermore, there is an age and sex difference between the sample studied by Glass and the sample of post-war immigrants in Canada. The latter contains a proportion of women who were excluded from Glass's study and, on the whole, the migrants are a younger generation. Excluding students and others not in the labour force, 54 per cent of the migrants were in non-manual employment in Britain compared with 37 per cent in Glass's sample. The proportion of skilled workers was almost exactly the same, 33 per cent, but the proportion of semi-skilled and unskilled workers was only 13 per cent compared with 29 per cent in the national sample studied by Glass. This confirms the underrepresentation of unskilled workers and the overrepresentation of white-collar workers among emigrants to Canada. Glass used an index of association to measure the extent to which children tended to have the same social status as their fathers. An index of unity implied perfect mobility. Glass found that, in his sample of adult males, the non-manual workers had an index of association of $\mathrm{r} \cdot 6$ compared with an index of $I \cdot 2$ for skilled manual workers and $I \cdot 8$ for semi-skilled and unskilled workers. It is only possible to make a very crude comparison with the migrants in view of the very small size of the sample. However, an examination of the proportion of those whose fathers were in non-manual

${ }^{15}$ For a discussion of the relation between occupational status and internal migration see, R. Illsley, A. Finlayson and B. 'Thompson, 'The motivation and characteristics of internal migrants', Milbank Memorial Fund Quarterly April and July 1963, 4r, 2 and 3.

${ }^{16}$ D. V. Glass, ed., Social Mobility in Britain, London, 1954. 
occupations and who were themselves in non-manual employment in the U.K., compared with the proportion that one would expect from the total proportion of non-manual workers in Glass's sample, would appear to give an index of association of $I \cdot 8$. The experience of migration for the children of white-collar workers was, as has been shown, to increase further the association between parental occupation and that of the migrant. Glass found an index of association for skilled manual workers of $\mathrm{I} \cdot \mathrm{I} 5$ arid the index for the migrant sample was almost exactly the same when the occupation in the U.K. was considered. However, there was a slight increase in the association between parental occupation and the occupation of migrants with fathers in this class when employment in Canada was considered. In the case of semi-skilled and unskilled workers, Glass found an index of association of $I \cdot 8$ while the index for the migrant sample was a negative one, suggesting that those whose fathers were in semi-skilled and unskilled employment had more than the expected proportion who had risen to skilled manual or non-manual status. However, the move to Canada slightly increased the association between the status of the parent and of the migrant for this group, bringing it close to unity, but the numbers are too small for the change to be regarded as significant. Only the most tentative and hypothetical conclusions can be drawn from this analysis. Provisionally, it would appear that emigrants to Canada from Britain whose fathers were in non-manual employment have a larger than expected chance of themselves being in non-manual employment in Britain, and that this expectation is further increased by their experience in Canada. Those with fathers in skilled manual employment have about the expected proportion who are themselves in skilled manual employment in Britain and a slightly higher proportion in Canada. In the case of those whose fathers were semi-skilled and unskilled workers, the proportion of the emigrants in this type of employment in Britain is below expectation but may be increased by the experience in Canada. Thus, it seems that for some sons and daughters of white-collar and skilled workers, emigration to Canada provided a means of avoiding downward mobility, relative to the occupation of the father. The migrant children of semi-skilled and unskilled workers tended already to be upwardly mobile, but emigration to Canada did not improve their status further.

TABLE 3. Blishen score difference between father's occupation and son's last occupation in Canada

SCORE DIFFERENGE

Blishen Points*

Up $\left\{\begin{array}{l}\text { II and higher } \\ 6-\text { ro } \\ 3-5 \\ 1-2\end{array}\right.$

No Change

Down $\left\{\begin{array}{l}1-2 \\ 3-5 \\ 6-10 \\ \text { I } 1 \text { and higher }\end{array}\right.$

Movement not known
NoN-U.K.

No. Per cent

$20 \quad 6.8$

$\left.\begin{array}{rr}24 & 8 \cdot 1 \\ 44 & 14 \cdot 9\end{array}\right\} 39 \cdot 0$

27

$46 \quad 15 \cdot 6$

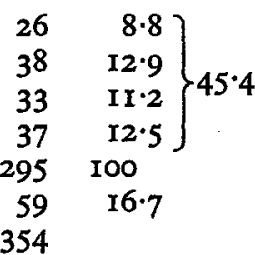

U.K.

$\left.\begin{array}{rr}\text { No. } & \text { Per cent } \\ 12 & 11 \cdot 9 \\ 9 & 8 \cdot 9 \\ 15 & \begin{array}{r}14.8 \\ 12\end{array} \\ 11.9\end{array}\right\} 43.5$

14

$\left.\begin{array}{rc}13 & 12.9 \\ 11 & 10 \cdot 9 \\ 6 & 5.9 \\ 9 & 8.9\end{array}\right\} 38.6$

Total

$\left.\begin{array}{rc}\text { No. } & \text { Per cent } \\ 32 & 8 \cdot 1 \\ 33 & 8 \cdot 4 \\ 59 & 14 \cdot 9 \\ 39 & 9 \cdot 8\end{array}\right\} 41 \cdot 2$

* Ignoring third digit (decimal point) in Blishen score.

$\mathbf{E}$ 
When U.K. immigrants and others are compared in terms of the overall degree of intergenerational mobility as measured by the Blishen score, the differences are comparatively small. ${ }^{17}$ (See Table 3.) This is despite the variation in class composition initially. At the time of the survey I 5 per cent of those about whom information was available had the same score as their father, or less than one Blishen point difference, and there was no variation between British immigrants and others. Of the U.K. immigrants 44 per cent had risen and 39 per cent had fallen, while 39 per cent of the others had risen and 45 per cent had fallen. These differences were not statistically significant. However, the purely quantitative measure ignores the qualitative differences in types of movement between classes to which attention has been drawn. It also ignores the range of downward movement which was greater in the case of non-U.K. immigrants.

\section{INTRAGENERATIONAL MOBILITY}

At this point it is appropriate to examine more closely the actual pattern of social status mobility exhibited by post-war immigrants in Canada, comparing their jobs in their former country with their first job in Canada, and the job at the time of the survey. The period of residence in Canada is clearly relevant to any examination of occupational status mobility. The maximum number of years that a post-war immigrant could have been resident at the time of the survey was 15 years and the minimum I year. The average for the sample as a whole was $7 \frac{1}{2}$ years. Thirty-eight per cent of the immigrants had been in Canada for 5 years or less, 42 per cent 5 to ro years, and 20 per cent II to is years.

The Blishen score provides a useful measure of the change in status between the job in the former country, the first job held for two months or more in Canada, and the job at the time of the survey. In order to appreciate the implications of the distribution of score differentials, it is useful to consider the number of points which certain typical movements up or down the scale involve. A worker in the construction industry, for example, who moved between unskilled labouring and a skilled job would gain or lose between three and four points. A skilled worker who became a foreman or vice versa would gain or lose three points. The difference between the score of a foreman and a manager in the construction industry was approximately 16 points. In the professional field, the movement from a school teacher to a university professor or vice versa would mean a gain or loss of four points and the difference between a practical nurse and a graduate nurse was $\mathrm{r} 3$ points. The difference between a dental mechanic and a qualified dentist was 32 points.

Forty-one per cent of all respondents about whom information was available had no change or a change of less than I point in their Blishen score between their job in their former country and the first job in Canada (Table 4). About I 5 per cent had a higher score and 44 per cent a lower score than formerly. There were significant differences between immigrants from the U.K. and from other countries in this respect. Thirty-seven per cent of those from other countries compared with

\footnotetext{
${ }^{17}$ Blishen scores movements exclude the 'not known' categories and ignore the third digit (decimal points) in Blishen scores.
} 
53 per cent of those from the U.K. had no change or a change of less than one point in their score. Approximately the same proportion, just under I 5 per cent of both groups, moved up, but a higher proportion of the non-British fell; 49 per cent compared with 33 per cent of those from the U.K. There was also a substantial difference in the degree of downward movement. In the case of immigrants from the U.K. the median downward movement was 4 Blishen points, whereas that of the immigrants from other countries was 7 . The highest upward movement experienced by a British immigrant in his first job in Canada was 14 points compared with a highest score of 10 points in the case of an immigrant from another country. The largest downward movement was 25 points in the case of one British, and 30 points in the case of one-non-British migrant. The most dramatic examples of scores falling 20 or more points were the consequence of migrants with higher educational and professional qualifications finding it impossible to obtain employment in their own fields and, consequently, being compelled to accept employment at the level of semi-skilled or unskilled workers in Canada.

\section{TABLE 4. Blishen score difference between occupation abroad and first occupation in Canada}

\begin{tabular}{|c|c|c|c|c|}
\hline SCORE & DIFFERENCE & & N-U.K. & \\
\hline & hen points* & No. & Per $c$ & cent \\
\hline & I I and higher & - & -7 & \\
\hline Up & 6 - ro & I I & $3 \cdot 9$ & .14 .8 \\
\hline $\mathbf{p}$ & $\begin{array}{l}3-5 \\
I-2\end{array}$ & $\begin{array}{r}24 \\
7\end{array}$ & $\left.\begin{array}{l}8 \cdot 4 \\
2.5\end{array}\right\}$ & $240^{\circ}+>$ \\
\hline No $\mathrm{Cr}$ & NGE & IO4 & $36 \cdot 5$ & \\
\hline & I -2 & 20 & $7 \cdot 0 ?$ & \\
\hline Down & $3-5$ & 42 & 14.7 & $48 \cdot 7$ \\
\hline Howne & $6-10$ & 43 & I5.1 & \\
\hline & I I and higher & 34 & II.9 & \\
\hline Moven & & $\begin{array}{r}285 \\
69\end{array}$ & 100 & \\
\hline 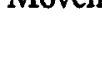 & 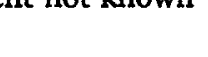 & 354 & 193 & \\
\hline
\end{tabular}

* Ignoring third digit (decimal point) in Blishen score.

When the first job in Canada is compared with the job at the time of the survey, it is found that a little under half of the immigrants experienced no change, or a change of less than I Blishen point in their score (Table 5). About 7 per cent had a lower score at the time of the survey and 46 per cent a higher score. The proportion of immigrants from the U.K. and from other countries who retained the same Blishen score or who rose, was approximately the same, but the proportion of British immigrants who fell was slightly higher, although the difference was not statistically significant. About 5 per cent of the sample had been in Canada for only about a year and might reasonably be expected to experience further mobility in due course. The overall mobility due to migration can be estimated by comparing the Blishen score of the migrant in his former country with that at the time of the survey. Table 6 shows that, at the time of the survey 43 per cent of all migrants, about whom information was available, had the same Blishen score as in 
their former country and the proportion was the same for U.K. immigrants and others. Thirty-one per cent had risen and 27 per cent fallen. A higher proportion of British had experienced upward and a smaller proportion downward mobility, but the differences were not statistically significant.

TABLE 5. Blishen score difference between first occupation and occupation in Canada, February I96I

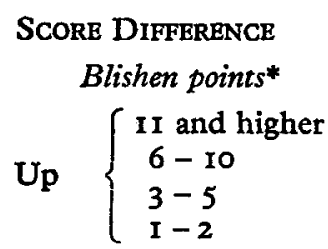

No Change

Down $\left\{\begin{array}{l}\text { I }-2 \\ 3-5 \\ 6-\text { IO } \\ \text { II and higher }\end{array}\right.$

Movement not known

\begin{tabular}{|c|c|c|}
\hline \\
\hline \multicolumn{2}{|c|}{$\begin{array}{l}\text { Non-U.K. } \\
\text { No. } \quad \text { Per cent }\end{array}$} & cent \\
\hline $2 I$ & 6.67 & \\
\hline 6I & 19.2 & $46 \cdot$ \\
\hline $\begin{array}{l}47 \\
10\end{array}$ & 14.8 & \\
\hline 19 & & \\
\hline 152 & $47 \cdot 8$ & \\
\hline 7 & $2 \cdot 2)$ & \\
\hline 7 & $2 \cdot 2$ & \\
\hline 4 & $I \cdot 2$ & \\
\hline 318 & $100^{-}$ & \\
\hline 36 & 10.2 & \\
\hline
\end{tabular}

U.K.

$\left.\begin{array}{rr}\text { No. } & \text { Per cent } \\ 12 & 10 \cdot 9 \\ 15 & 13 \cdot 6 \\ 10 & 9 \cdot 1 \\ 10 & 9 \cdot 1\end{array}\right\} 4^{2 \cdot 7}$

$5 I \quad 46 \cdot 4$

$\left.\begin{array}{rc}5 & 4.5 \\ 5 & 4.5 \\ 1 & 0.9 \\ 1 & 0.9 \\ 110 & 100 \\ 14 & 11 \cdot 3 \\ 124 & \end{array}\right\}$ I0.8

Totac

No. Per cent

$\left.\begin{array}{rr}33 & 7 \cdot 7 \\ 76 & 17 \cdot 8 \\ 57 & 13 \cdot 3 \\ 29 & 6.8\end{array}\right\} 45 \cdot 6$

$203 \quad 47 \cdot 4$

$\begin{array}{rc}12 & 2 \cdot 8 \\ 12 & 2 \cdot 8 \\ 5 & 1 \cdot 2 \\ 1 & 0.2 \\ 428 & 100 \\ 50 & 10.5 \\ 478 & \end{array} 7^{-0}$

TABLE 6. Blishen score difference between occupation abroad and occupation in Canada, February I96I

SCORE DIFFERENCE

Blishen points*

Up $\left\{\begin{array}{l}\text { II and higher } \\ 6-10 \\ 3-5 \\ \text { I }-2\end{array}\right.$

No Change

Down $\left\{\begin{array}{l}1-2 \\ 3-5 \\ 6-10 \\ \text { I I and higher }\end{array}\right.$

Movement not known
NoN-U.K.

No. Per cent

$\begin{array}{ll}6 & 2 \cdot 1 \\ 1 & 5 \cdot 9\end{array}$

$17 \quad \begin{array}{rr}5 \cdot 9 \\ 40\end{array} 28 \cdot 5$

$\begin{array}{rr}40 & 13.9 \\ 19 & 6.6\}^{28}\end{array}$

I2I $\quad 42 \cdot 2$

$\left.\begin{array}{rc}13 & 4 \cdot 5 \\ 40 & 13 \cdot 9 \\ 18 & 6 \cdot 3 \\ 13 & 4 \cdot 5 \\ 287 & 100 \\ 67 & 18 \cdot 9 \\ 354 & \end{array}\right\}^{29 \cdot 2}$

U.K.

No. Per cent

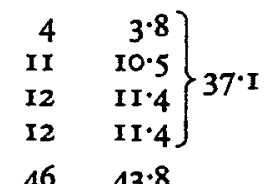

$46 \quad 43 \cdot 8$

$\left.\begin{array}{rc}8 & 7 \cdot 6 \\ 6 & 5 \cdot 7 \\ 3 & 2 \cdot 9 \\ 3 & 2 \cdot 9 \\ 105 & 100 \\ 19 & 15 \cdot 3 \\ 124 & \end{array}\right\} 19 \cdot 1$

TOTAL

$\left.\begin{array}{rc}\text { No. } & \text { Per cent } \\ \text { I0 } & 2 \cdot 6 \\ 28 & 7 \cdot 1 \\ 52 & 13 \cdot 3 \\ 31 & 7 \cdot 9\end{array}\right\} 30 \cdot 9$

* Ignoring third digit (decimal point) in Blishen score.

\section{Comparisons of Special Matched Groups}

Due to the heterogeneity of the samples it is doubtful whether the tests of significance applied to the Blishen score movements are a strictly valid indication of the differences between U.K. and non-U.K. immigrants. The use of a $\chi^{2}$ test in such cases assumes that the groups being compared have equal statistical chances of rising or falling. This was manifestly not the case, since the U.K. group had a larger proportion in the higher social classes in their former country and, therefore, a greater theoretical chance of falling. By the same token non-U.K. migrants tended to start nearer the bottom and consequently their purely statistical chances of rising were superior to the U.K. group. 
In order to overcome this difficulty and to allow for other differences between the samples, two special matched groups of U.K. and non-U.K. migrants were compared. The comparison was confined to males between the ages of 24 and 55 years who had been in Canada five years or more and who had expressed an original intention to remain in Canada rather than re-migrate. Immigrants from all non-European countries were eliminated from the non-U.K. group as were refugees from East European countries. The groups so matched also had a similar distribution of marital status and of Blishen social class in their former country. If language and nationality had ceased to be important determinants of social class after migrants with similar education and class backgrounds in their former country had been in Canada for more than five years, then the distribution of Blishen score movements at the time of the survey should have exhibited no significant difference. Table 7 shows that, in fact, a larger proportion of U.K. migrants rose and a smaller proportion fell in status. When the 'not known' cases are eliminated, the differences are of an order that would occur less than $I$ in 20 but more than $I$ in 40 times in a simple random sample of the same size. It is reasonable to conclude, therefore, that U.K. immigrants in Canada did have some advantage over non-U.K. immigrants, when other things were equal, but that this advantage was a comparatively small one.

TABLE 7. Special matched groups of migrants. Blishen score difference between occupation in former country and in Canada, February $196 \mathrm{I}$

$\begin{array}{lccccc} & \text { Higher } & \text { Same } & \text { Lower } & \text { Not known } & \text { Total } \\ \text { U.K. } & \text { 13 } & \text { 15 } & 7 & 2 & 37 \\ \text { Non-U.K. } & 4 & \text { 16 } & 12 & 5 & 37\end{array}$

\section{Movements between Socio-economic Classes}

Although the Blishen score gives a useful quantitative estimate of social mobility, an analysis by socio-economic classes throws more light on some qualitative aspects of the movement. In particular it draws attention to important differences in the experience of manual and non-manual workers, especially those who were not from English-speaking countries.

Table 8 shows intragenerational movements in terms of the socio-economic classes, and confirms the differences between U.K. immigrants and others in their first job in Canada. Whereas 77 per cent of the British immigrants who were formerly in white-collar occupations retained this status in their first job in Canada, only 32 per cent of the immigrants from other countries did so. Those who fell into manual employment were twice as likely to enter the lowest category rather than Class 5, for which they would rarely have suitable qualifications. For example, seven out of ten non-U.K. immigrants who had been in higher managerial posts in their former country fell in status, all of them into manual employment, and only one out of the seven entered Class 5 . U.K. immigrants who fell from Classes I or 2 were more likely to remain in non-manual employment, but clerical workers from the U.K. and from other countries who failed to retain their status were more likely to drop to Class 6 . 
TABLE 8. Intragenerational mobility of post-war immigrants in Canada. (Outflow analysis) NON-UNITED KINGDOM ORIGIN

JOB IN CANADA

\begin{tabular}{c|cc|cc|cc|cc|cc|}
\hline & \multicolumn{2}{|c|}{$I-4$} & \multicolumn{2}{|c|}{5} & \multicolumn{2}{c|}{6} & \multicolumn{2}{|c}{7} & \multicolumn{2}{c}{ Total } \\
\hline $\begin{array}{c}\text { Job in } \\
\text { county of } \\
\text { origin }\end{array}$ & $\begin{array}{c}\text { First } \\
\text { Per } \\
\text { cent }\end{array}$ & $\begin{array}{c}\text { I96I } \\
\text { Per } \\
\text { cent }\end{array}$ & $\begin{array}{c}\text { First } \\
\text { Per } \\
\text { cent }\end{array}$ & $\begin{array}{c}\text { I96I } \\
\text { Per } \\
\text { cent }\end{array}$ & $\begin{array}{c}\text { First } \\
\text { Per } \\
\text { cent }\end{array}$ & $\begin{array}{c}\text { I96I } \\
\text { Per } \\
\text { cent }\end{array}$ & $\begin{array}{c}\text { First } \\
\text { Per } \\
\text { cent }\end{array}$ & $\begin{array}{c}\text { I96I } \\
\text { Per } \\
\text { cent }\end{array}$ & $\begin{array}{c}\text { Per } \\
\text { cent }\end{array}$ & No. \\
\hline $1-4$ & 32 & 54 & $2 I$ & 25 & 43 & 17 & 4 & 4 & 100 & 84 \\
5 & - & 5 & 42 & 68 & 56 & 24 & 2 & 3 & 100 & 94 \\
6 & - & 3 & 8 & 14 & 86 & 80 & 6 & 3 & 100 & 119 \\
7 & 14 & 32 & 7 & 25 & 46 & 35 & 33 & 8 & 100 & 57 \\
\hline
\end{tabular}

UNITED KINGDOM ORIGIN

JOB IN CANADA

\begin{tabular}{l|rr|rr|rr|rr|rr}
\hline $1-4$ & 77 & 74 & 8 & 12 & 13 & 7 & 2 & 8 & 100 & 61 \\
5 & 8 & 30 & 70 & 57 & 22 & 13 & - & - & 100 & 37 \\
6 & 7 & 7 & - & 33 & 80 & 47 & 13 & 13 & 100 & 15 \\
7 & 18 & 46 & 9 & - & 27 & 18 & 46 & 36 & 100 & 11 \\
\hline
\end{tabular}

* Code: I 4 Non-manual.

5 Highly skilled.

6 Other skilled, semi-skilled and unskilled.

7 Not in labour force and not known: includes students and other non-employed together with those about whom information was not available.

There were considerable differences between the experience of immigrants from the U.K. and from other countries, who were formerly in Class 5 . Whereas 70 per cent of the skilled workers from the U.K. retained this status in their first job in Canada, only 42 per cent of those from other countries did so. The remainder of the non-U.K. group fell into the lowest class, whereas some of the skilled workers from Britain entered clerical employment. There was less difference in the experience of semi-skilled and unskilled workers in Class 6, only 7 per cent of whom improved their status in their first job in Canada, irrespective of origin.

When the situation at the time of the survey is examined, it appears that some of the non-U.K. migrants who were in white-collar employment in their former country, but who fell initially into the manual category, had at least partially recovered their position. The proportion in non-manual employment had risen from 32 to 54 per cent, but only 40 per cent had actually returned to their original class. Skilled workers did rather better. By the time of the survey 68 per cent were in their 
former class and 5 per cent had moved into non-manual employment. There was only a slight decline in the proportion in the lowest class, compared with the first job in Canada, although 17 per cent had moved up mainly into more highly skilled manual employment.

In the case of immigrants from the U.K. there was very little difference between the position of former non-manual workers at the time of the survey compared with their first job in Canada. About the same proportion were still in manual employment, although the more detailed figures show that some who had dropped from the managerial, professional or intermediate classes subsequently recovered their position. Recovery or improvement upon their former position was most marked in the case of highly skilled workers. Only 13 per cent of this class were still downwardly mobile and 30 per cent had moved to non-manual employment, mainly in Class 4. A substantial number of those formerly in Class 6 moved up into Class 5 by the time of the survey.

\section{CONCLUSION}

The overall picture suggests that immigrants from the U.K. began with a very strong advantage in so far as they had fewer language problems to overcome and their occupational qualifications were more immediately acceptable to Canadian employers. This initial advantage diminished over a time as immigrants from other countries became more acculturated. Although British immigrants continued to be markedly underrepresented in the lowest social class and overrepresented in nonmanual employment, compared with other immigrants and the Canadian population as a whole, the overall degree of upward mobility achieved by migration was hardly any higher than that of the non-British. Semi-skilled and unskilled manual workers stood the greatest chance of improving their status by entering employment requiring greater skill, although hardly any, even from the U.K., entered the white-collar category. Non-manual workers, particularly those who were not from English-speaking countries, suffered the largest initial decline in status and had the greatest difficulty in recovering.

In interpreting the evidence concerning both intergenerational and intragenerational mobility, it must be remembered that the subjective significance of movement for the individual concerned may differ from the objective implications for a system of stratification. There may have been some sons who did not wish to follow their father's footsteps in a white-collar job and some migrants who positively preferred an outdoor job to one in an office, particularly if the decline in status did not necessarily mean a fall in the migrant's standard of living. Since the standard of living in Canada generally is high, so long as a migrant was fortunate enough to avoid prolonged unemployment or ill-health, he could improve his material conditions despite a fall in status. In fact, 8 per cent of the immigrants said that their standard of living had risen in Canada although their position in the community had fallen; only 3 per cent said that their position in the community and their standard of living had both fallen. 


\section{APPENDIX}

\section{TESTS OF SIGNIFICANCE}

TABLE I.: Socio-economic status of immigrants and their fathers

\begin{tabular}{clll} 
Father's & \multicolumn{2}{c}{ DIFFERENCES BETWEEN U.K. AND OTHERS } \\
Former \\
Class I-3 & No significant difference. & Class I & $P<0.025$ \\
& & & \\
4 & $P<0.05$ & 2 & No significant difference. \\
5 & $P<0.025$ & 3 & $P<0.001$ \\
6 & $P<0.001$ & 4 & $P<0.01$ \\
& & 5 & No significant difference. \\
& & 6 & $P<0.001$ \\
First in Canada & Canada I96I \\
Class I & $P<0.01$ & Class I & $P<0.001$ \\
2 & No significant difference. & 2 & No significant difference. \\
3 & $P<0.001$ & 3 & $P<0.001$ \\
4 & $P<0.001$ & 4 & $P<0.001$ \\
5 & No significant difference. & 5 & No significant difference. \\
6 & $P<0.001$ & 6 & $P<0.001$
\end{tabular}

TABLE 2:

NON-U.K.

Fathers' occupations compared with migrants' in former country:

No significant movement in either direction

Fathers' occupation compared with migrants' in Canada 1961:

Movement from non-manual to manual: McNemar test of change (one-tailed): $P<0.05$

Movement from non-manual to manual between former country and Canada 1961 of children of non-manual fathers: McNemar test of change (one-tailed): $P<0.005$

U.K.

Fathers' occupation compared with migrants' in former country:

No significant movement in either direction

Fathers' occupation compared with migrants' in Canada 196r:

Movement from manual to non-manual: McNemar test of change (one-tailed): $P<0.05$

Movement from manual to non-manual of children of non-manual fathers: McNemar test of change (one-tailed): $P<0.05$

TABLE 3:

Blishen score movement between father's occupation and that of migrant in Canada, 1961 .

No significant difference between U.K. and others.

TABLE 4:

Blishen score movements between occupation abroad and first occupation in Canada.

Significantly less downward mobility of U.K. $P<0.025$

TABLE 5:

Blishen score movement between first occupation in Canada and occupation in February 1961.

No significant difference between U.K. and others. 


\section{TABLE 6:}

Blishen score movement between occupation abroad and occupation in Canada, February 196I. No significant difference between U.K. and others.

\section{TABLE 7:}

Special matched groups. Difference between U.K. and Non-U.K. $P<0.05$.

\section{TABLE 8:}

NON.U.K.

First occupation in Canada compared with former country:

Movement from non-manual to manual: McNemar test of change (one-tailed): $P<0 \cdot 00$ I

Movement from skilled to semi- and unskilled:

McNemar test of change $P<0.001$

Occupation in Canada I961 compared with former country:

Movement from non-manual to manual:

McNemar test of change (one-tailed): $P<0.001$

Movement from skilled to other:

McNemar test of change - no significant change in either direction.

U.K.

First occupation in Canada compared with former country:

Movement from non-manual to manual:

McNemar test of change (one-tailed): $P<0.025$

Movement from skilled to semi- and unskilled:

McNemar test of change (one-tailed): $P<0.025$

Occupation in Canada 1961 compared with former country:

McNemar test of change - no significant changes in any direction. 